\title{
The Inimitable F. N. David: A Renaissance Statistician
}

Amanda L. Golbeck and Craig A. Molgaard

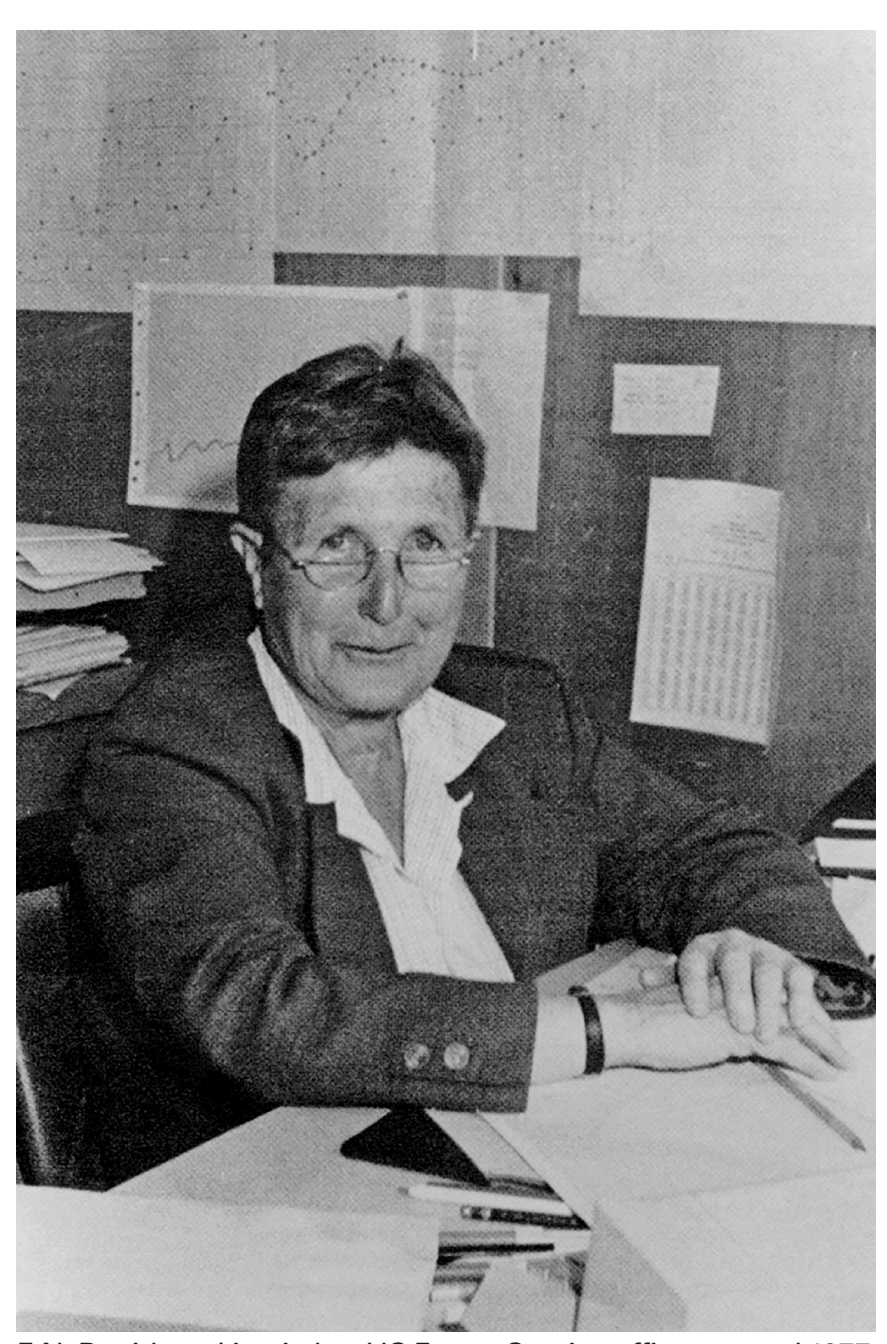

F. N. David working in her US Forest Service office, around 1977.

Amanda L. Golbeck is a professor of biostatistics and the associate dean for academic affairs in the Fay W. Boozman College of Public Health at the University of Arkansas for Medical Sciences. Her email address is ago1beck@uams.edu.

Craig A. Molgaard is a professor of public health and codirector of the program in rural and global public health in the Fay W. Boozman College of Public Health at the University of Arkansas for Medical Sciences. His email address is camolgaard@uams.edu.

Communicated by Notices Associate Editor Richard Levine.

For permission to reprint this article, please contact: reprint-permission aams.org.

DOI: https://dx.doi.org/10.1090/noti2246

\section{Highlights}

Florence Nightingale David (1909-1993) was known to readers of her scholarly publications as "F. N. David" and to her colleagues as "David" or "FND." David has been recognized as the leading, most accomplished and most memorable British woman statistician of the mid-20th century ([11], [14]). She was a professor at University College London (UCL), and then at the University of California (UC). When we were graduate students in the early 1980s at UC-Berkeley, where David had an affiliation before and after her retirement from UC-Riverside, she was already a legend in statistics.

"Enormous energy" and "prolific output." These are words that statistician D. E. Barton wrote in an obituary to describe his close UCL colleague. Barton added that these qualities were part of what made David "an exciting colleague to work with" [1]. These qualities are also what make it difficult to pigeonhole David's illustrious 60-yearlong career, which was packed with probability and statistical ideas. The numbers alone make clear the extent of her immense energy and output: She wrote nine books, over one-hundred published articles, over fifteen secret (classified) war reports, and various forest service white papers. She was working on a tenth book and other articles and papers when she died.

David's life as a statistician began at age 22, when she walked into Karl Pearson's office at UCL in 1931 and asked him for a job. Pearson (1857-1936) was in his mid 70s and an enormous intellectual figure, a protégé of Sir Francis Galton (1822-1911). Pearson had built the world's first university statistics department at UCL twenty years earlier, in 1911 [24]. He was acknowledged to be a Renaissance scientist, that is, a broad thinker (see [20]). He did, after all, write The Grammar of Science in 1892. When he retired, it took three people to fill his job.

David was Pearson's last statistics protégé. It is no wonder David took after him and became a Renaissance statistician. David worked in the department Pearson founded for most of her career. This was 29 years in all, between 1931-1939 and 1946-1967. She rose up the academic ranks from research assistant to full professor. David's many accomplishments at UCL include the following:

1. David worked with renowned statisticians Egon S. Pearson (1895-1980, the son of Karl Pearson), Jerzy 
Neyman (1894-1981, founder of the UC-Berkeley statistics department), and William Sealy Gosset (1876-1937, publishing under the pseudonym "Student" because he worked in industry) on "a thorough consideration of the fundamentals of statistics" [1].

2. She collaborated with statisticians Egon Pearson and Norman Johnson (1917-2004) to further the excellence of the undergraduate program in statistics and to develop the statistics department into both a research center and a center for post-graduate studies.

3. She became the first faculty member in the statistics department to be titled in both probability and statistics.

4. She was the first woman in the statistics department to be promoted to the rank of professor.

David's academic career at UCL was interrupted by World War II. The British government put her to work doing critical military research for six long years (1939-1945). Among David's accomplishments for the war effort are the following:

5. David conducted vital civil defense research with Frank Garwood on plans for evacuating London during the German Blitz, as well as the civilian populations of other British cities.

6. She conducted critical research with Sir Austin Bradford Hill (1897-1991) and others on mass bombing casualties in Britain, known as the Bombing Census.

7. She worked on the placement of anti-tank mines in the African desert in the campaign against Rommel.

The UC recruited David in 1967. She emigrated to the United States and finished her career at UC-Riverside and UC-Berkeley, while doing significant contract work for the US Forest Service. Among David's accomplishments are the following:

8. David was the founding chair of the department of statistics at UC-Riverside.

9. She was one of the first women to be a research university chairperson in the sciences in the United States.

10. She was an amazing storyteller, a skill that won her a distinguished teaching award at UC-Riverside.

11. She was the first winner of the prestigious Committee of Presidents of Statistical Societies (COPSS) Elizabeth L. Scott Award.

Long after her death in 1993, David continues to be remembered by statisticians across the globe.

12. In 2000, COPSS established an award named after her, the COPSS Florence Nightingale David Award.

13. In 2018, COPSS named a lecture after her, the COPSS Florence Nightingale David Lecture.
The first David award was presented to Nan Laird in 2001. The first David Lecture was given by Susan S. Ellenberg in 2019. This was the first lecture named after a woman that was ever given at the Joint Statistical Meetings (JSM) [7].

In this paper, we aim to introduce readers to F. N. David and her contributions to statistics. In order to tell more of David's story, we accessed archival materials and conducted site visits on two continents, researched published literature and web articles, and conducted interviews with people who knew her. We stumbled upon benefactors like Emma Styles, Funding and Development Officer of the Colyton Grammar School Academy Trust in the United Kingdom. Our research is ongoing, for example, we are still searching for evidence of a rumored connection beyond the David family and the Florence Nightingale (1820-1910) family that extends beyond the namesake. Here we will feature some elements of the David story that piqued our interest, especially drawing from our own research, a "conversation article" [12], David's newly unclassified war reports, several interviews with statistician Jim Baldwin in 2019, and a presentation by statistician Roxy Peck who participated with us in an invited session that we organized at the 2019 JSM. Baldwin and Peck both knew David when they were doctoral students at UC-Riverside. Baldwin served as David's head teaching assistant; David recruited him to the US Forest Service, where he spent most of his career.

David was a prodigy, warrior, professor, writer, leader, and celebrity. She was an inimitable statistician.

\section{Prodigy}

David spent eight years (1931-1939) at UCL before World War II. She was a West England girl, growing up within sight of Offa's Dyke, the ancient boundary between England and Wales. In fact, her father was of Welsh descent. Both of her parents were school teachers; her father was a headmaster. David was a new college graduate when she had the temerity to knock on Karl Pearson's door at UCL.

Pearson saw promise in David: he gave her a start as a statistician by renewing her scholarship so that she could pursue graduate studies in statistics. As his research assistant, she ably helped him carry out his projects and edit the journal Biometrika. Reflecting back on this time in her life, David told Baldwin that Pearson would look at her and just shake his head at her, because she was a woman. She told Laird that he was the only person who truly scared her, but he was also very kind.

In her first year on the job, David received a published acknowledgement. William Sealy Gosset (aka "Student") 
published an article in Biometrika on the z-test [25]. Karl Pearson wrote a review that appeared with the article in which he mentioned David. Student had proposed that the $z$-test was suitable for use in small samples with highly correlated individuals. Pearson doubted that this would be good practice. David produced random samples from a population so that Pearson could conduct a series of experiments to lend evidence to his argument.

In her second year on the job, David became a published author. She was only 23 years old. She worked on a Bessel function problem together with Pearson and sociologist Samuel Stouffer (1900-1960) that was published in Biometrika [19]. The purpose of the paper was to discuss an alternative to the ratio method for dealing with certain coefficients.

Thus, David quickly established herself as a statistics prodigy. David's first acknowledgement was by Pearson. Her first publication — which was a hefty 58 pages longwas with Pearson. At the time, Pearson was viewed in the statistics community as the god of the discipline.

In the early 1930s, the professoriate at UCL and other research universities was almost exclusively male. UCL appointed its first woman to the rank of professor in 1949 [10, p. 213]. David nonetheless thrived as a young woman academic. There were several enabling factors.

One is that UCL had a liberal philosophy and global outlook. The university was built upon the great social reformer Jeremy Bentham's philosophy that education should be made available to all, not just the wealthy. The auto-icon of Bentham (1748-1832) that still greets you in the main building at UCL is a physical reminder of the university's philosophist tradition. Today UCL boasts that it was the first university in England to accept students of any race, class, or religion. It also asserts that it was the first to accept women and men on equal terms. Yet the whole time David was at UCL, the staff common rooms were segregated by gender. Thus, even though David found an opening within the Bentham-style liberal philosophies, she did not find complete relief.

A second likely reason that David did well at UCL is that Karl Pearson was a progressive and broad thinker with a long interest in gender issues, and he created a work culture that included women. When David approached him for a job, Pearson already had employed and promoted a number of brilliant women. We will mention two here. Alice Lee (1858-1939) was one of the first women to earn a PhD at UCL; she became a research lecturer in applied mathematics. Ethel Elderton (1878-1954) worked her way up to the position of reader at UCL. Lee and Elderton didn't rise to the position of professor, but it could be argued that they helped to pave the way for David.

A third likely reason that David did well at UCL is that she arrived there with a stellar educational background and love for learning. At age five, her parents arranged for the rural church parson to teach her algebra, Greek, and
Latin. At age 11, David won a scholarship to a top school, Colyton Grammar School. David was Head Girl there four years in a row. This was a significant position, being akin to a student council president in the United States. David won many academic honors and prizes at the school, especially in mathematics and English. At age 19, she won a major merit scholarship that she used to attend Bedford College for Women and then UCL. She graduated from Bedford with a BSc in pure mathematics. David was well prepared to pursue graduate studies at UCL.

David's first eight years at UCL (in the 1930s) coincided with a seminal period in statistics. The biggest names in statistics were present. Karl Pearson's son Egon succeeded him as professor and head of the UCL statistics department. Jerzy Neyman was a reader in the department for four years (1934-1938). Neyman and Pearson are known for having developed, among other things, the modern theory of hypothesis testing that included the concepts of type I and type II errors, power, and simple versus composite hypotheses [13]. Ronald A. Fisher (1890-1962) was a professor and developed, among other things, the analysis of variance, maximum likelihood, and foundations of the design of experiments [2]. The statistics department was a magnet for people like William Sealy Gosset (aka "Student") who is best remembered for developing the $t$-test [18]. David sized it up by saying that she "saw all of the protagonists from a worm's eye point of view" [12].

In the prewar years, David had a seat at the table with these major actors. She achieved many milestones during this period: She was promoted to lecturer in 1935, published an enduring book on correlation in 1938 (see section 5), earned a PhD in 1938, and wrote her first of a series of papers on Neyman's smooth test of goodness of fit. David was a rising star among stars. She was a bridge between first generation (like Karl Pearson) and second generation (like Jerzy Neyman) modern statisticians. See, for example: https://en.wikipedia.org/wiki/Guy_Meda1.

Then World War II happened.

\section{Warrior}

David engaged in work related to World War II during the period 1939-1945. She transitioned back to UCL during the period 1945-1947, when statistics department staff reconstructed the department and completed their war work.

David was a highly effective and ubiquitous warrior during World War II. She was a crucial part of the statistical brains of the Royal Air Force located at Princes Risborough. She helped to conduct the Bombing Census of Great Britain with Sir Bradford Hill. She carried out detailed statistical analyses of the casualties and damage to English cities. These analyses led to the plans for bombing operations against Nazi-controlled Europe that helped end the war and bring peace.

These actions began for David in 1938 in what was known as "the Czech Crisis." Great Britain and Germany 
butted heads over the border between Germany and Czechoslovakia, amid mutual recriminations and threats. All assumed war was imminent, which would bring on strategic bombing of population centers. David served on a planning committee for the evacuation of London's population to safer rural areas, such as Wales, during this period. She also created statistical models to predict damage from potential German bombing to high-density areas and populations in London and other English cities. These included possible numbers living and dead, reactions to fires and damaged buildings, damage to communications and utilities, etc.

By September 1939, the war began for real. On the very day that Hitler invaded Poland (September 1, 1939) the British government drafted five statisticians to work at UCL on the war effort. The five were David, Egon Pearson, Norman L. Johnson, B. L. Welch, and D. J. Bishop. They were transferred from UCL to the Ordinance Board at the Ministry of Supply.

It was known at the time, but is not well remembered, that Winston Churchill (1874-1965) recognized the value of quantitative insights. He began his interest in quantitative research with studies of comparative attrition from the Somme Battle in 1916 in World War I among the British and German armies involved. He disputed the English War Office statistics on the Somme Battle, and used German and British archival material to prove that attrition occurred on both sides during that battle, but was far worse for the English. This analysis was a major part of Churchill's book, The World Crisis. His primary point there was that General Haig was wearing out the English army faster than he was wearing out the German army. It was a splendid example of a military vital statistics analysis ([15]; https://winstonchurchi11.org /publications/finest-hour/finest-hour-172 /battle-of-the-somme-2/).

Churchill was largely responsible for bringing "the quantifiers" from Oxford, Cambridge, and UCL into the British World War II effort. Churchill's vision from 1939 as First Lord of the Admiralty and from 1940 as Prime Minister was that new statistical services and organizations were needed to manage quantitative information as it increased during the war. This led to the creation of the S-Branch (later known as the Prime Minister's Statistical Section) under the direction of Frederick Lindeman (1886-1957), an Oxford physics professor. This organization was tremendously active during the war, among other things working on quantitative problems of national economics, defense equipment, machine tools, shipping, rationing, and manpower reports. The last included the Beveridge Report on social insurance, which led to the creation of-and still influences-the British health care system.

David partnered with Edward van Rest, Bradford Hill, and Egon Pearson on multiple statistical projects in the first years of the war. This included development of the Bombing Census (with van Rest and Bradford Hill, beginning in
November 1940) and problems of anti-aircraft gunnery (with Egon Pearson). This research was mainly supported by the Royal Air Force (RAF).

The initial goal of the Bombing Census was to assess the bomb distribution and effects over the entire country (from 1940 to 1945 around 61,000 British citizens were killed in these raids). For example, what was the frequency and nature of injuries and causes of death when domestic homes and shelters were bombed? The resulting bomb plots and supporting information for each and every German raid were passed on to the Ministry of Home Security Research and Experiments Branch for analysis. Data were collected on a form designed by Bradford Hill. Bradford Hill was the senior statistician on this project, and David was the deputy statistician.

The statisticians carried out most of the analysis at the data center at Special Section No. 8 at Princes Risborough, Buckinghamshire. This was where David lived and worked for most of the war (1942-1945), in very austere circumstances in shared quarters with two other women. Princes Risborough, because of its analytic strengths, was known as "the Brains of the RAF" [21, p. 194].

The commanding officer of this Special Section was Squadron Leader Dewdney, an expert on oil production and transportation. Dewdney eventually surmised that the English bombing raids on continental Europe oil plants were heavily overestimating effects, describing them as "delusional." This led to the Butts Report of 1941, which heavily criticized RAF bombing raids that commonly missed their targets by ten miles.

The Bombing Census findings were used to project damage from British bombing raids to German industry and housing throughout the war. David was deeply involved in this reverse engineering analysis, especially on German raid data from London, Birmingham, Coventry, and Liverpool.

What did the statisticians learn? They learned that concentrated use of incendiary bombs, followed by high explosive bombs to cause drafts, was the most effective technique of air assault against large industrial centers. One author noted that "Damage was heaviest in the congested working-class districts, which suggested that these were optimal targets" [16, p. 56]. The goal then became attacking the homes and lives of industrial workers living near factories to limit their productivity.

To summarize, statisticians such as David were called in to study the effects of the bombings by the Germans on England (defensive damage assessment: 1939-1941). As the war turned in favor of the allies, data from the initial damage assessments were used to mount effective offensive operations against the Axis powers (1942-1944). The British returned to conducting research on defensive planning and techniques in the second half of 1944 and 1945 as a result of the German introduction of $\mathrm{V}-1$ and $\mathrm{V}-2$ robot bombs. David was deeply involved in finding the robot bomb launching sites in France, Belgium, and the Netherlands to target allied air power on the sites to destroy them. 
As the war wound to a close, David was also heavily engaged in research on clearing mines from beaches as allied beach assaults began in 1944. Earlier she had helped train British troops to use random number tables when laying mines to protect tank parks in the western desert of Africa when fighting Rommel and the Afrika Corps. David also trained American statisticians such as Neyman at Princes Risborough in British bombing strategy and tactics to be used in finishing the war with Japan. Neyman stayed at Risborough with David for six weeks in late 1944 studying these British approaches.

It is our opinion that no other British statistician carried out such a wide range of applications for the war effort, with the possible exception of Frank Yates (1902-1994) at Rothamsted Experimental Station. This included production of twenty classified statistical papers from 1942 to 1945 for the Ordinance Board and the Research and Experiments Department R.E. 8. Her work also took her outside of England as when she flew to Philadelphia in 1944 for a site visit of the first electronic general purpose super computer (the ENIAC-Electronic Numeral Integrator and Computer), whose first program was a study of the feasibility of thermonuclear war. Following German surrender in 1945, she was asked to join the American Manhattan Project in planning the atomic attacks on Japan.

David turned the Manhattan Project invitation down. She had had enough of war, and instead returned to UCL in 1946 and began helping to restore the libraries there, as the campus had been badly damaged by incendiary bombing on two different occasions. David began to organize and transport library books from the Welsh salt mines, where they had been stored for safety from the wartime blitz, to the UCL campus.

\section{Professor}

After the war, David returned to UCL in 1946. She picked up where she left off in her faculty role. In all, she remained at UCL until 1967. During this time, David researched and published articles on distribution of chromosomes, mapping of karyographs (a method of displaying characteristics of chromosomes), diversity in ecology, spread of forest fires, symmetric functions, k-statistics, experimental design, history of probability, combinatorics, correlation, least squares, goodness of fit, and sampling theory. David's work on space-time interaction in epidemics, with its emphasis on person-to-person infection, surely can inform current day coronavirus modeling. David wrote 10 papers with Norman Johnson on statistical aspects of experimental design, and about 30 on diverse combinatorial problems and their statistical applications [1].

During this period, David earned a DSc in 1952. In the United Kingdom, the DSc is a higher degree than the $\mathrm{PhD}$. The many reviewers of David's work described it as rigorous, sound, careful, meticulous, substantial, sturdy, useful, and notable.
There is an adage in higher education that those who publish early will publish often. This certainly applied to David. She was a prolific scientific author with considerable breadth and depth. She authored over 100 journal publications in all, not counting her classified war papers or her white papers for the US Forest Service. She had a continual output of publications, many of which are still cited today. Barton wrote in her obituary: "Her contribution to statistics was wide-ranging and substantial." One of David's doctoral students, Colin Mallows (of Mallow's $C_{p}$, which assesses model fit in ordinary least squares regression), said this about David: "I admire her continual output of research papers. I think this 'rubbed off' on me since I have been trying all my life to complete the next paper and get it published" (Mallows, 2018, personal communication).

In support of her many successes at UCL, David had the backing of a number of champions. We will mention three.

Egon Pearson. After becoming professor and head of the statistics department, Egon Pearson promoted David multiple times in recognition of her outstanding work. Eventually he promoted her to the position of reader. In the British system, the only higher faculty position was professor. Egon Pearson was a champion of David, but his championship had its limits. Many thought that she was qualified to succeed Egon Pearson as professor and head of the statistics department. But when he retired, Egon Pearson made sure that David did not succeed him by arguing to his provost that she did not have the temperament for the position. According to Lehmann [14, p. 117], “...prejudice against women prevented her appointment...."

Maurice Bartlett. His support of David was unqualified. It was Bartlett (1910-2002) who succeeded Egon Pearson as the professor and head of the statistics department. In the British system, the norm was to have one professor who was also the chair. Bartlett could have enjoyed his position as the sole professor in the department. But David's work was so exceptional that he decided to make things right for her, at least as right as he could. He promoted her to the rank of professor, making her only the fourth person (after Karl Pearson, Egon Pearson, and Bartlett) to hold the rank of professor in the department. It was almost unheard of to be a professor without the department head responsibilities. It speaks volumes about both Bartlett as a person and David as a prolific scholar.

Jerzy Neyman. He was without a doubt David's biggest supporter. David met Neyman in 1934 when he came to work in the department of statistics at UCL. She was his first graduate student there. He is credited with insisting she finish her $\mathrm{PhD}$. The two taught probability together, and she wrote her second book on this course material (see section 5). She became the first reader in the statistics department to be titled in both statistics and probability. David and Neyman became lifelong colleagues and friends.

When Neyman died in 1981, there was a memorial session for him at the European Meeting of Statisticians. 


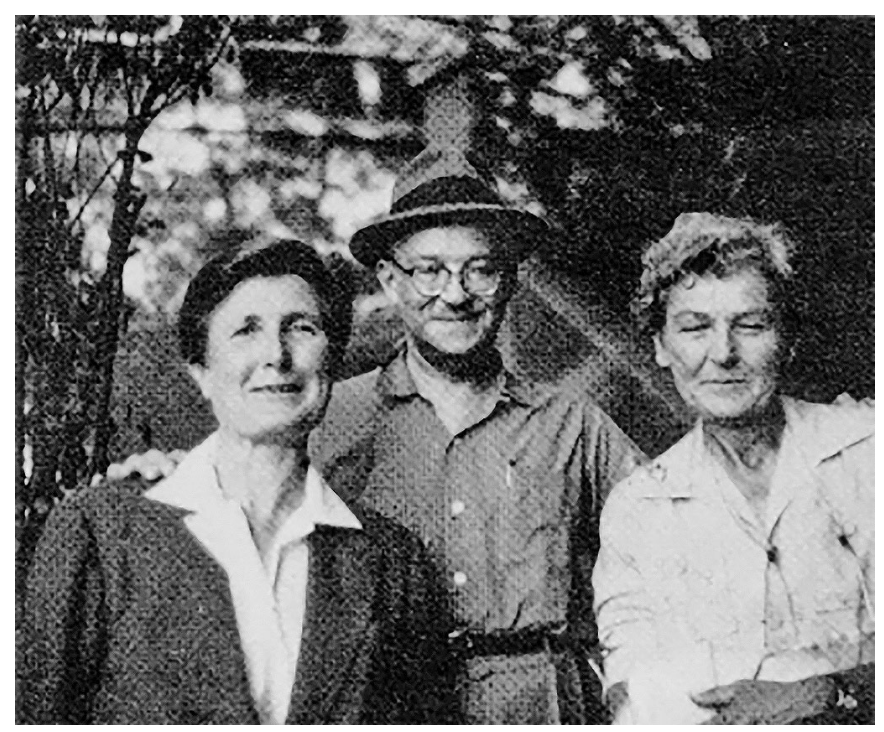

Figure 2. F. N. David (left) with her close friends and colleagues Jerzy Neyman and Evelyn Fix at Berkeley in 1960.

David was a speaker. She said this about him: "I knew him over 50 years. He could be quite impossible and we quarreled strongly every six months or so. But I loved him" [3]. David had a strong personality. She would, without hesitation, tell you what was on her mind. But this didn't get in the way of her having very close professional and personal relationships.

\section{Writer}

David loved books. She wrote, cowrote, or edited nine of them on a variety of subjects:

1. David, F. N. (1938). Tables of the Ordinates and Probability Integral of the Distribution of the Correlation Coefficient in Small Samples. Cambridge University Press.

2. David, F. N. (1949). Probability Theory for Statistical Methods. Cambridge University Press. Second edition, Cambridge University Press, 1951.

3. David, F. N. (1953). A Statistical Primer. Charles Griffin \& Company. Second edition as A First Course in Statistics, Charles Griffin \& Company, 1971.

4. David, F. N. and Pearson, E. S. (1961). Elementary Statistical Exercises. Cambridge University Press.

5. David, F. N. (1962). Games, Gods and Gambling: The Origins and History of Probability and Statistical Ideas from the Earliest Times to the Newtonian Era. Charles Griffin and Company. Second edition as Games, Gods and Gambling: A History of Probability and Statistical Ideas, Dover Publications, 1998.

6. David, F. N. and Barton, D. E. (1962). Combinatorial Chance. Charles Griffin and Company.

7. David, F. N. (1966). Research Papers in Statistics: A Festschrift for J. Neyman. John Wiley and Sons.

8. David, F. N., Kendall, M. G., and Barton, D. E. (1966). Symmetric Functions and Allied Tables. Cambridge University Press.
9. David, F. N., Barton, D. E., Ganeshalingam, S., Harter, H. L., Kim, P. J., Merrington, M., and Walley, D. (1968). Normal Centroids, Medians, and Scores for Ordinal Data, Tracts for Computers, Vol. XXIX, Cambridge University Press.

These books helped to propel the use of statistics in science, to set a standard for the teaching of statistics, and to promote the understanding of statistics and statisticians in historical contexts.

One collection of David's books greatly facilitated the use of statistics in scientific research at a time before the field transitioned to the use of computational algorithms to compute probabilities. David's three books of statistical tables of probability integrals were definitive, and she produced them with great care. Her first book of tables, written when she was only 29 years old, was a monumental contribution to the correlation coefficient (David, 1938; reprinted as recently as 2009). Using three mechanical Brunsviga calculating machines in series, she computed exact probability integrals of the sample correlation coefficient with 20-figure accuracy. A second book of tables was a major contribution to combinatorics (David, Kendall, and Barton, 1966, as a companion to the theoretical book David and Barton, 1962). In this book, David and her coauthors summarized "all of the techniques which we have found useful and paved the way for further research work" on symmetric functions (p. x). A third book of tables was an important contribution to the analysis of ordinal or very non-normal data (David et al., 1968). It was primarily concerned with normal centroids, normal medians, and normal scores. All three books contained tables that had a high degree of accuracy, with almost no errors. Importantly, they also contained detailed, theoretical introductions to the subjects that gave readers the foundations they needed to use the tables with skill. These sections of the books could have easily stood alone as important monographs.

Another collection of David's books helped to set a firm foundation for the teaching of statistics and development of the statistics workforce. These books were original, rigorous, and authoritative. One was a book on probability theory for statistical methods, based on some of David's lectures at UCL (which she conducted with Neyman and continued after he left UCL for UC-Berkeley) to second-year mathematics students who wanted to learn some statistics (David, 1949). Here David described the mathematical theory of probability as "a bridge, however inadequate it may seem, between the sharply defined but artificial country of mathematical logic and the nebulous shadowy country of what is often termed the real world." Another book was a first course in statistics, based on some of her lectures to life scientists across nearly all science departments at UCL (David, 1953, later updated and republished as David, 1971). David wrote that it was for scientists who were "able to digest simple statistical ideas and such mathematical symbols as are necessary to formulate them." A third book which was written with Egon Pearson was on elementary 
statistics and covered topics from the earlier parts of the UCL statistics curriculum, up to, but not including, the Analysis of Variance (David and Pearson, 1961). A fourth book on combinatorial chance was less of a textbook and more of a reference book for the working statistician (David and Barton, 1962). Combinatorial chance was a subject where David "had both technical fluency and insight" [1]; Feller [4] wrote that the authors "feel that combinatorics can be fun, and they try to communicate this feeling...." In general, David cared about explaining difficult statistical concepts in a simple, straightforward, and engaging manner; illustrating these concepts with a wide variety of meaningful examples; promoting student practice of the manipulation of real-world data; and making her enthusiasm for the subjects known and infectious.

Standing proudly alone in a category was David's classic book on the history of probability, titled Games, Gods and Gambling: A History of Probability and Statistical Ideas (David, 1962). This was the first book on the history of probability theory to be published in 100 years. It is still read today after having seen multiple reprintings by multiple publishers. The book contains both prehistory and history, beginning with ancient Egypt and ending with the death of de Moivre in the middle of the 18th century. It is filled with "interesting facts and fresh ideas." This is no wonder, as David used many kinds of historical sources in the book (as she did in her teaching), and also poetry, classical literature, and archaeology. It was David's philosophy that: "the man creates the mathematical theorem, but the events of a man's life create the man, and the three are indissoluble." David's book blends biographies and social environments with assessments of discoveries, making the book very readable. A reviewer wrote: David's "keen interest in the personalities makes itself felt on almost every page, but it is equaled by her profound knowledge of the subject matter" [23].

Also of special mention is the book Research Papers in Statistics (David, 1966), which David edited as a Festschrift for her close friend and colleague Neyman, to celebrate his 70th birthday. A reviewer wrote: "Jerzy Neyman has put all statisticians in his debt by his numerous contributions ... The present volume...is an expression of the affectionate esteem in which colleagues the world over hold Jerzy Neyman...I can think of no more fitting tribute [than David's book] to [Neyman's] assured place in the annals of statistical theory" [5]. The book was a collection of several dozen papers, on a wide range of topics, and from a who's who of theoretical and applied statisticians: Egon Pearson, Maurice Bartlett, Joe Berkson, David Cox, Harold Cramer, David Kendall, Lucien LeCam, Paul Levy, George Polya, Herman Wald, and others. When you start to develop an edited book, you always wonder if people will write for you. All of these major players in the field of statistics were willing to write insightful chapters for David.

In addition to her nine books, David was a consulting editor or book editor for several journals. She wrote many of the book reviews herself. For example, a 1961 issue of a journal contained 31 book reviews, with David authoring 10 of them. David also had many doctoral students at UCL and was a highly appreciated research mentor. This was evidenced by the thanks given to her in the bound copies of the dissertations that we reviewed in the UCL statistics library. David's love for books propelled her to devotedly help to rebuild the UCL library system after significant World War II bombing damage.

\section{Leader}

In 1967 at age 58, David packed her bags and left UCL to emigrate to the United States. Neyman, her longtime colleague and friend, had earlier reached a barrier to advancement at UCL and emigrated to the United States to become the founding chair of the statistics department at UC-Berkeley. Now David's circumstances were similar, and she became the founding chair of the statistics department at UC-Riverside. As mentioned, David was one of the few women researchers in the sciences to break into academic administration [22]. This was an accomplishment that followed Gertrude Cox (1900-1978) who became a chair in 1941 at North Carolina State University, and that David shared contemporaneously with Elizabeth L. Scott (19171988) who became a chair in 1968 at UC-Berkeley [6].

Right before David emigrated, Bartlett resigned his position as head of the statistics department at UCL. Dennis Lindley (1923-2013) was hired to be his replacement as head. If Neyman was a draw for David to go to UC-Riverside, Lindley was a push for her to go. Lindley was a leading advocate of Bayesian statistics. David was a frequentist to the core. Statistician Roxy Peck recalled that, "at a conference [David] took some [UC-Riverside] graduate students to, if somebody came up to give a talk on Bayesian statistics, she took her cane and shook it and left the room knocking over her chair as she left" [17]. Perhaps it is no surprise, given David's intellectual bond with Neyman, that she had no use for Bayesian statistics.

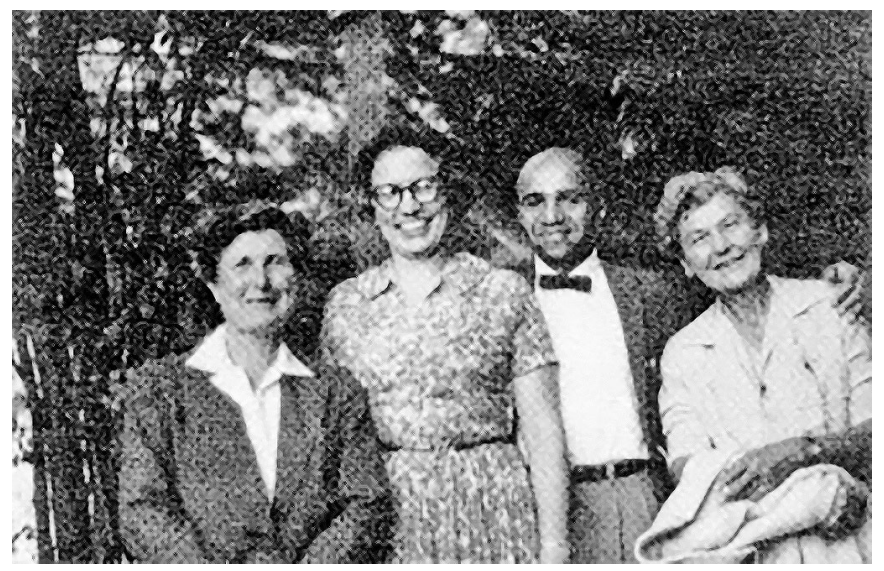

Figure 3. F. N. David visiting Berkeley from UCL in 1960. With Berkeley statisticians Elizabeth L. Scott, David Blackwell, and Evelyn Fix. 
This story illustrates that David used a cane, and she used it to do more than assist with walking. As a young woman, she had a motorbike accident that caused her to often carry a cane. In Riverside, she used her cane to help clear a pathway for others. In Berkeley, she liked to wrap her fist around the middle of the cane and wave it at drivers to get them to stop so that she could cross the street. Her cane was a prop. It was part of her persona and act.

David was a clever and savvy administrator at UCRiverside. She was creative at getting students and skillful at procuring resources, to the point where the mathematics department was jealous of her and wanted her investigated. They failed. Baldwin describes the years of problems with the math department as the "war years"; they were "very tense," and she was fighting with "all men."

When there were departmental meetings at UCRiverside, David invited staff as well as faculty so that all could contribute. All were welcome. This was an example of inclusive leadership, long before the term ever existed.

David was a beloved and award-winning teacher. This was true both at UCL and UC-Riverside, but she is particularly remembered for her teaching skill while at Riverside. There she mainly taught at the introductory level. For example, she taught a general education class, using her book Games, Gods and Gambling. Her excitement for the subject was palpable.

David also taught a doctoral seminar on topics in the statistics literature. Students gave presentations, and these were heavily critiqued by both David and the other students in the class. The seminar was not for the faint of heart, but it thoroughly prepared students for competing in the job market and presenting papers at professional conferences. David was very supportive of the statistics graduate students. Baldwin remembers her attitude about working with applied scientists: "You wanted to learn something about the applied field but not too much so that you thought like them. That was really important to her. You needed to speak the language of whatever applied field it was, but you didn't want to know too much about it, is what she kept telling us" (Baldwin, 2019, personal communication). David understood how statisticians can advance science by looking at applied problems with fresh and independent eyes.

In California, David explained her accent at the beginning of each course, telling her students that she spoke the pure King's-or Queen's-English. Her voice was loud and crystal clear. She was a great storyteller. As a teacher, she painted a picture of statistics with meaningful examples drawn from a wide variety of real applications. She would walk around the room talking, which was way ahead of her time in terms of teaching pedagogy. Her classes were packed, often with as many as 200 students in a class. Eventually her class became too popular-her class size increased to 450-500 people-it was so large that it became unmanageable, so it was discontinued.

David had a strong sense of determination. As a girl, she wanted to be an actuary, but the profession at the time was largely closed to women. She reportedly was turned down for an actuary position when it was discovered that she was a woman. Her father told her she should not cry and give up, but instead she should get on with her work. This she did. And she passed along this message and attitude to her students. Peck remarked: "She was a role model [for her students], but she was not a typical role model. She could be a bit cantankerous, feisty, smoked cigars. None of us actually pictured our future to be like her. But we also knew that we weren't part of her league in terms of statistical abilities. But the thing about David is that she allowed you to see the possibilities of what you could accomplish if you worked hard. And what she valued was people who would work hard for what they wanted" [17]. As a result, David had tremendous respect from her students.

David was tough: her stares were like laser beams, and those exposed felt like they could be deadly. But she joked around a lot, too, mainly in a sarcastic way. She also occasionally practiced physical humor, where she could have a pretty powerful punch. She was beloved by colleagues and students alike, for both her fiery temper and her wonderful story-telling ability. She was a role model in the mathematical sciences, but in no ways was she typical.

David retired from her position at UC-Riverside in 1977. Baldwin recalls that she "just got tired of it." She had gotten the Riverside department going, and it was running well, so "she probably figured it was time...." David had strong relationships at UC-Berkeley with Neyman, Scott, Evelyn Fix (1904-1965), and others in the Bay Area statistics community. She had been commuting between Riverside and Berkeley every week for almost ten years, which is a long time to do a seven-hour commute in each direction.

After becoming Emeritus Professor, David continued to teach at UC-Berkeley and consult for the US Forest Service. She recruited Baldwin, one of her former UC-Riverside statistics graduate students, to work at the Forest Service as well. He recalled that she was interested in the measurement of natural populations, and she "described some simple-minded approaches for counting things and testing where there were trends in bird populations... Birds was a big thing for her when I was in the Forest Service. She had her two-bang theory for counting birds. It was somewhat sarcastic on her part, or maybe a whole lot sarcastic. It went like this: if birds were in a tree, you'd take a shotgun and fire to get the birds out of the tree, and then you'd use the shotgun again to shoot the birds and count them once they were on the ground. The two-bang method" (Baldwin, 2019, personal communication). It is an example of David's wry sense of humor.

In 1993 in the Bay Area, David transitioned to the afterlife. Being British to the core, she had her body shipped back to the United Kingdom. It is laid to rest in the lovely English village of Graffham where she kept her vacation home. Sadly, her grave is unmarked. There is no stone marking the final resting place of this very strong woman and leader in statistics. 


\section{Celebrity}

COPSS established the Elizabeth L. Scott Award. The first award was given in 1992, and it is given every other year. David was the inaugural recipient: for her efforts in opening the door to women in statistics; for contributions to the profession over many years; for contributions to education, science, and public service; for research contributions to combinatorics, statistical methods, applications, and understanding history; and her spirit as a lecturer and as a role model. It is interesting that David and Scott were personal friends. Their careers ran in parallel on both sides of the Atlantic.

About ten years later, COPSS partnered with the Caucus for Women in Statistics to establish another award named after a woman that would alternate with the Scott award. They chose to name it after David. The first award was given in 2001. It recognizes an individual who exemplifies David's excellence in research, leadership of multidimensional teams, statistics education, and service to the professional societies. A history of the David Award is given in [8].

In 2018, COPSS unanimously decided to accept a proposal to elevate the Elizabeth L. Scott Award to the Elizabeth L. Scott Award and Lecture, and to elevate the Florence Nightingale David Award to the Florence Nightingale David Award and Lecture. These lectures are delivered at the JSM. They have the same format and standards as the former Fisher Lecture. The first Florence Nightingale David Lecture was given in 2019, and the first Elizabeth L. Scott Lecture was given in 2020. The David lecture was the first lecture named after a woman that was ever given at the JSM.

Golbeck articulated the significance of these new lectures at a meeting of the Caucus for Women in Statistics in 2018. As she put it,

The JSM has been held every year since 1840 . This means that over the past 178 years, men and women who have been attending the JSM have not seen one single lecture named after a woman. The JSM is the largest gathering of statisticians in North America, and one of the largest in the world. Each year there are over 6,000 participants from over 50 countries. These huge numbers of men and women have been attending the JSM without seeing one single lecture named after a woman...ALL of us-men and women, of all ages-in our profession need to see strong human, female faces: faces like Elizabeth $L$. Scott and F. N. David ([7], address to the Caucus for Women in Statistics).

These lectures serve as more than lectures. The people who the lectures are named after, and the people who give the lectures, serve as role models who can instruct, inspire, and motivate statisticians to achieve greater successes.

When David started out, there were few women statisticians. Today there are many more: women account for $43 \%$ of the doctoral recipients in doctoral-granting statistics and biostatistics departments in the United States [9] and 35\% of the members of the American Statistical Association (https://magazine.amstat.org/blog/2016/02/01 /genderupdate16). It is fitting that there are now lectures named after two women who were brilliant trailblazers in statistics.

\section{Inimitable Statistician}

David's British parents gave her a big name. Her namesake, Florence Nightingale, who died only two years before David was born, was the first woman named to the prestigious Order of Merit. Parents like David's who named their children after Florence Nightingale were perhaps hoping that the name could instill confidence, if not mystique. David certainly had both qualities. She was instrumental in developing the field of statistics on two continents.

David saw her job as one of asking questions and trying to find the answers. She was one of the broadest statisticians of her time. Another Renaissance person and statistician, J. B. S. Haldane (1892-1964), was very impressed with David and wrote this about her: "...a number of people with fellowships of the Royal Society and the like are narrow specialists compared with Dr. David...." Florence Nightingale David was a woman of letters, a Renaissance statistician.

Peck collected words that have been used to describe David. These included "feisty, unconventional, persistent, uncompromising, independent, prolific, generous, and charming" [17]. David liked to smoke Turkish cigarettes. She apparently started smoking cigars in the war because they were easier to get than Turkish cigarettes. Her colleagues at the US Forest Service in California used to collect her cigar boxes. Baldwin described her as "loud and round, and inspirational" (Baldwin, 2019, personal communication).

Both authors of this paper knew David. When Golbeck was a graduate student in statistics and biostatistics at UC-Berkeley, David interviewed her for a consulting position at the US Forest Service. Golbeck received the position. Molgaard took a class in international health while a graduate student in public health at UC-Berkeley, where David was a guest lecturer. She was, on a personal level, marvelously eccentric as well as brilliant.

At Berkeley in the 1980s, David relaxed and favored wearing cowboy boots, a cowboy shirt, and blue jeans. When teaching she liked to talk at length about her namesake. Florence Nightingale was known as the lady of the lamp. It is fitting that David ended her academic career at UC-Berkeley, where the university motto is "let there be light."

No one who met David ever forgot her.

\section{Conclusion}

Why should you know about F. N. David? She was a major player among the most major players in the building of the field of statistics in Great Britain and the United States. 
Because she was so prolific and her work was so strong, the other major players had enormous respect for her, and she prospered against all odds as a woman within the profession. She succeeded at UCL up to the highest glass ceiling, and then she was recruited to UC-Riverside where she broke that ceiling.

What do we gain by knowing the F. N. David story? As epidemiologists put it, we gain a sense of person, place, and time in our contextual understanding of the field of statistics between 1930 and 1967. The importance of David to the development of the field is that she witnessed all of the great statistical theoretical developments of her time and contributed to an impressive number of them. She brought enormous energy to her work, was willing to work under very difficult conditions, and dedicated herself to do whatever it took to solve a problem.

David was a remarkable statistician and leader. Her prolific writing covered a broad range of topics and interests. Even though she lost seven years of academic productivity doing service work during the war, she rose up higher on the academic ladder in Britain than almost any other woman in science of her time, and she was a rare woman academic department chair in the research sciences in the United States. On the basis of our research, David was a "ceiling-cracker" for women in the statistical sciences profession. Further evidence of this is the establishment of the COPSS F. N. David Lecture, given for the first time at the 2019 Joint Statistical Meetings.

\section{References}

[1] David Barton, Obituary: Florence Nightingale David, J. Roy. Statist. Soc. Ser. A 157 (1994), no. 2, 299-301. MR1274405

[2] Joan Fisher Box, R. A. Fisher: The life of a scientist, John Wiley \& Sons, New York-Chichester-Brisbane, 1978. MR500579

[3] D. R. Cox, Some pioneers of modern statistical theory: a personal reflection, Biometrika 103 (2016), no. 4, 747-759, DOI 10.1093/Diomel/asw052. MR3620437

[4] W. Feller, Review. Gombinatorial Chance by F. N. David and D. E. Barton, Biometrika 50 (1963), nos. 1/2, 225.

[5] J. Gani, Review: Research papers in statistics edited by F. N. David, Rev. International Statistical Institute 35 (1967), no. 3, 322-323.

[6] Amanda L. Golbeck, Equivalence-Elizabeth L. Scott at Berkeley, CRC Press, Boca Raton, FL, 2017. MR3642319

[7] Amanda L. Golbeck, Statistical association presidents establish Elizabeth L. Scott, F. N. David Lectureships, AmStat News, June 1, 2018.

[8] Amanda L. Golbeck, A caucus for women in statistics: Supporting an inclusive community, Significance Magazine (Special issue: Florence Nightingale) 17 (2020), no. 2, 42-44.

[9] Amanda L. Golbeck, Thomas H. Barr, and Colleen A. Rose, Report on the 2017-2018 new doctorate recipients, Notices Amer. Math. Soc. 67 (2020), no. 8, 1200-1206.

[10] Negley Harte, John North, and Georgina Brewis, The World of UCL, UCL Press, 2018.

[11] Norman L. Johnson and Samuel Kotz (eds.), Leading personalities in statistical sciences: From the seventeenth century to the present, Wiley Series in Probability and Statistics: Probability and Statistics, John Wiley \& Sons, Inc., New York,
1997. A Wiley-Interscience Publication. MR1469759

[12] Nan M. Laird, A conversation with F. N. David, Statistical Science 4 (1989), no. 3, 235-246.

[13] E. L. Lehmann, Jerzy Neyman: April 16, 1894-August 5, 1981, Biographical Memoirs, vol. 63, National Academy of Sciences, Washington, DC, 1994, pp. 395-420.

[14] E. L. Lehmann, Reminiscences of a statistician: The company I kept, Springer, New York, 2008. MR2367933

[15] Craig Molgaard, Military vital statistics: The Spanish flu and the First World War, Significance Magazine 16 (2019), no. 4, 32-37, 24 July 2019.

[16] Richard Overy, The bombers and the bombed: Allied air war over Europe, 1940-1945, Viking Press, 2013.

[17] Roxy Peck, Games, gods and gambling: In the classroom with F. N. David, Celebrating the new COPSS Florence Nightingale David Lecture (Invited Papers), Joint Statistical Meetings, Denver, CO, 8/1/2019.

[18] "Student": a statistical biography of William Sealy Gosset, The Clarendon Press, Oxford University Press, New York, 1990. Based on writings by E. S. Pearson; Edited and augmented by R. L. Plackett; With the assistance of G. A. Barnard.MR1255103

[19] Karl Pearson, S. A. Stouffer, and F. N. David, Further applications in statistics of the $T_{m}(x)$ Bessel function, Biometrika 24 (1932), nos. 3/4, 293-350.

[20] Theodore M. Porter, Karl Pearson: The scientific life in a statistical age, Princeton University Press, Princeton, NJ, 2004. MR2054951

[21] Constance Reid, Neyman-from life, Springer-Verlag, New York, 1982. MR680939

[22] Margaret Rossiter, Women scientists in America: Before Affirmative Action 1940-1972, Johns Hopkins University Press, 1995.

[23] Christoph J. Scriba, Review: Games, Gods and Gambling by F. N. David, Isis 55 (1964), no. 2, 216-218.

[24] Stephen M. Stigler, The History of Statistics: The Measurement of Uncertainty Before 1900, Harvard University Press, 1986, ISBN 978-0-67440341-3. Chapter 10: Pearson and Yule.

[25] Student (with K. Pearson), On the " $z$ " test, Biometrika 23 (1931), nos. 3/4, 407-415.

[26] D. R. Wilkey, Review: A Statistical Primer by F. N. David, Biometrika 41 (1954), nos. 1/2, 281-282.

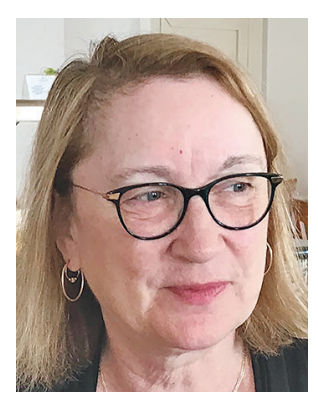

Amanda L. Golbeck

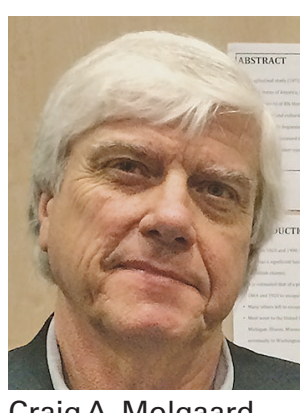

Craig A. Molgaard

\section{Credits}

Opening photo and Figures 2 and 3 are courtesy of the Institute of Mathematical Statistics.

Figure 1 is reprinted with permission of John Wiley \& Sons, from Jessica Utts, Obituary: Florence Nightingale David, 1909-1993, Biometrics 49 (1993), no. 4. Permission conveyed through Copyright Clearance Center, Inc.

Author photos are courtesy of the authors. 